INDEPENDENT JOURNAL OF MANAGEMENT \& PRODUCTION (IJM\&P)

\title{
THE RELATIONSHIP OF KNOWLEDGE MANAGEMENT AND ORGANIZATIONAL PERFORMANCE IN SCIENCE AND TECHNOLOGY PARKS OF TEHRANTehran
}

Mohammad Ali Haghighi Faculty of Management and Accounting, Shahid Beheshti University, Tehran, Iran E-mail: m-haghighi@sbu.ac.ir

Rouhollah Bagheri Faculty of Management and Accounting, Shahid Beheshti University, Tehran, Iran TehranE-mail: R_Bagheri@Sbu.ac.ir

Parisa Sabbagh kalat Islamic Azad University, Tehran, Iran E-mail: Pari.sabbagh@gmail.com

Submission: 07/11/2014 Accept: 04/12/2014

\section{ABSTRACT}

Any effective and sustainable changes in an organization refers to three areas related with each other and play the best way in the humans, structure and technology fields. The Knowledge management by emphasizing the three areas with the axis of man and preparing him as a knowledge worker tries to achieve organizational goals.

Purpose: The current study aims to investigate the existing relationship between knowledge management infrastructures, knowledge management process capabilities, creative organizational learning, and organizational performance.

Originality/value: Previous researches did not appraise the effect of knowledge management and its capabilities on organizational performance, and the specific influence of creative organizational learning was disregarded. The present study demonstrates the mechanism of knowledge management effect on organizational performance and describes the comprehensive dimensions of knowledge management performance. 
Methodology: Statistical population includes executives of Knowledge based companies in Science and Technology Parks of Iran. The 336 questionnaire was distributed to the census, 248questionnaireswerecompletedcorrectly. The research data were analyzed by PLS software. The unit of analysis is a company that has adopted a KMS. Target population of the research consisted of 700 Top Managers of Knowledge based companies in Science and Technology Parks of Iran ( $N=700)$. Random sampling method applied in this study and 248Top Managers were considered as the statistical sample based on "Morgan Table". One standard 5-point Likert questionnaire adopted and distributed between Top managers in the park. 252 questionnaires were returned among which 248 ones were statistically investigated. The structural relations among variables were tested using the partial least squares (PLS) method.

Findings: This study shows that the KM processes can mediate between creative organizational learning and factors in the KM infrastructure. The results of the study demonstrate that a knowledge management process capability has the most crucial role in creative organizational learning. The results indicate that there is a significant influence of the infrastructure capabilities (Collaboration, Trust, Learning Culture, Decentralization, Top Management, Promotion, IT support) on the process capabilities, also the impacts of knowledge management process capabilities on creative organizational learning and the impacts of creative organizational learning on organizational performance was confirmed.

Keywords: knowledge management, knowledge management infrastructure capabilities, knowledge management process capabilities, creative organizational learning, organizational performance.

\section{INTRODUCTION}

Knowledge is regarded as the main and invaluable asset in new ultracompetitive environments in developed countries, since knowledge is the only factor which can evoke change and innovation in organizations. Today, applying knowledge is one of the fundamental challenges of developing countries. A knowledge-oriented business is one of the essential goals of the fourth development plan of Tehran.

This cannot be reached without considering knowledge application in enhancing the capacity of different industries' production. The most important 
INDEPENDENT JOURNAL OF MANAGEMENT \& PRODUCTION (IJM\&P)

http://www.ijmp.jor.br

v. 6 , n. 2, April - June 2015

ISSN: 2236-269X

DOI: $10.14807 / i j m p . v 6 i 2.282$

proceeding in the fourth development plan is undeniably knowledge management. Satisfying the three criteria of International Bank of Reconstruction and Development (IBRD), which are economic liberalization, government modernization and knowledge-oriented economics, is not possible without conducting many researches and projects.

Achieving this goal, management researchers try to therefore present applicable and efficacious resolutions to make the organizations capable of applying knowledge management. Organization for Economic Co-operation and Development (OECD) focuses on the knowledge-based economy and the role of knowledge in economic developments in third millennium.

Recently, many researches have been conducted in accordance with knowledge management in the business world (METAXIOTIS; ERGAZAKIS; PSARRAS, 2005), and this conclusion can be drawn that economy has been changed into knowledge-based economy, and knowledge is considered as the most essential and invaluable competitive property in the organizations (RIVERA-VAZQUEZ; ORTIZ-FOURNIER; FLORES, 2009).

Therefore, the enhancement of knowledge management implementation can be seen in different organizations (MILLS; SMITH, 2011). The present study intends to examine the relationship between knowledge management infrastructure capabilities, knowledge management process capabilities, creative organizational learning, and organizational performance.

\section{THEORETICAL BACKGROUND OF THE RESEARCH}

\subsection{Knowledge management}

According to Stonier, data is a series of disconnected facts and observations. These facts may be converted to information by analyzing, cross-referring, selecting, sorting, summarizing or in some way organizing the data. Patterns of information, in turn, can be worked up into a coherent body of knowledge (ZINS, 2007). Knowledge can be classified into two types of tacit and explicit (NONAKA; KONNO, 1998).

Knowledge management framework consists of activities such as recognizing, gaining, creating, storing, sharing, and applying knowledge by people and groups in an organization (SUN, 2010). In this respect, Wen (2009) defines knowledge 
INDEPENDENT JOURNAL OF MANAGEMENT \& PRODUCTION (IJM\&P)

http://www.ijmp.jor.br

v. 6 , n. 2, April - June 2015

ISSN: 2236-269X

DOI: 10.14807/ijmp.v6i2.282

management as sets of procedures for creating, gaining, sharing and applying knowledge to improve organizational performance.

\subsection{Knowledge management capabilities}

Knowledge management supports the aggregation of resources into capabilities. Knowledge management capabilities can be categorized into two broad types. Knowledge infrastructure capability and knowledge process capability (MILLS; SMITH, 2011). Considering the conducted researches, two types of knowledge management capabilities can be posited which are knowledge management infrastructure capabilities and knowledge management process capabilities (GOLD; MALHOTRA; SEGARS, 2001; LEE; SUKOCO, 2007; AUJIRAPONGPAN et al. 2010; MILLS; SMITH, 2011).

\subsection{Knowledge management infrastructure capabilities}

It refers to the activities which support knowledge management system and create some competitive advantages in the organization. Gold, Malhotra and Segars (2001) identify information technology, organizational structure, and culture as infrastructure capabilities, and Khalifa and Liu (2003) while advancing Gold, Malhotra and Segars (2001) proposition establish leadership, culture and KM strategy as infrastructure required to develop a KM initiative.

Prior research recognizes the importance of having a supportive and effective knowledge infrastructure to underpin a firm's knowledge management initiatives. Different elements make up a firm's knowledge infrastructure capability (MILLS; SMITH, 2011).

Previous studies have suggested that knowledge infrastructure includes culture, people, organizational hierarchy, structure, and IT Lee and Choi (2003), Gray and Durcikova (2005) while Lee and Choi (2003) suggested that culture, structure, people, and information technology are related enablers for KM, management related factors that are important antecedents for KM process capabilities were missing in the study. Thus, this study suggests that KM infrastructure is composed of four groups of KM enablers: culture, structure, management, and technology. 
INDEPENDENT JOURNAL OF MANAGEMENT \& PRODUCTION (IJM\&P)

http://www.ijmp.jor.br

v. 6 , n. 2, April - June 2015

ISSN: 2236-269X

DOI: 10.14807/ijmp.v6i2.282

\subsection{Knowledge management process capabilities}

Knowledge management processes are of considerable importance in order to reinforce the organization to gain, transfer and apply knowledge efficiently (NGUYEN; NECK, 2010). Dimensions of Knowledge management process capabilities (GOLD; MALHOTRA; SEGARS, 2001).

- Knowledge Acquisition

- Knowledge Conversion

- Knowledge Application

- Knowledge protection

\subsection{Creative organizational learning}

Creative organizational learning is the extent to change the understanding of existing business practices or make them invalid (VANDENBOSCH; HIGGINS, 1996). Creative organizational learning is the amount of alteration in the comprehension of existing methods of business or knowing them as invalid approaches (VANDENBOSCH; HIGGINS, 1996). Creative organizational learning is based on strengthening creativity, enhancement of insights, generation of new viewpoints on existing ideas, and constructively criticizing existing opinions on businesses.

While many firms have developed KMS, companies that have considered the effect of KM on organizational learning are few. Enhanced KM processes through IT can increase organizational learning. For instance, Knowledge directories enable the interconnection of employees who have specialized creative knowledge that has not been publicized in organizations (RUGGLES, 1998).

\subsection{Organizational performance}

Organizational performance is consisting of the capabilities of product development, novel services, prediction of business and risks, and improving the ability of encountering new data in the market (GOLD; MALHOTRA; SEGARS, 2001). Organizational performance is a multi-dimensional concept which examines the organization's condition in comparison to competitors (MCKEEN; ZACK; SATYENDRA, 2006). 
INDEPENDENT JOURNAL OF MANAGEMENT \& PRODUCTION (IJM\&P)

http://www.ijmp.jor.br

v. 6 , n. 2, April - June 2015

ISSN: 2236-269X

DOI: 10.14807/ijmp.v6i2.282

\subsection{Knowledge management process capabilities and creative organizational learning}

Creative organizational leaning can be defined as the degree an organization's members can upgrade and promote their knowledge and enhance their understanding about new environments using new knowledge (RUGGLES, 1998). The achieved knowledge from organizations and outside experts can provide the potentiality of creative organizational learning based on changes in the existing organizational processes.

\subsection{Creative organizational learning and organizational performance}

Researchers in the field of knowledge management put emphasis on the role of learning in knowledge management, and mutual relationship between learning and knowledge (MASON, 2004). Pfeffer (2005) indicated that organizational comprehension can determine organizational performance, and creative organizational learning creates impressive innovations in organizational performance (PFEFFER, 2005). KM performance should be explained as the performance from the use of knowledge obtained from the KMS. In order to fully understand the performance of $\mathrm{KM}$, organizational learning outcomes should be evaluated as a measure of KM performance (TIWANA, 2002).

\subsection{Past Researches}

Although knowledge and its management have been linked to organizational performance dating back to 1982, the linkage has become even more critical in this k-economy era (CHONG et al., 2002). Lee and Sukoco (2007) found that knowledge management capabilities affect innovation and organizational effectiveness (LEE; SUKOCO, 2007).

Kulkarni et al. (2007) examined a KM success model that incorporated the organizational support structure as a contributing factor to the success of the KMS implementation (KULKARNI; RAVINDRAN; FREEZE, 2007).

Previous studies on KM have been fragmented because they only consider some aspects of KM performance rather than using a holistic view of the KM performance framework: they have examined the relationship between one or two 
INDEPENDENT JOURNAL OF MANAGEMENT \& PRODUCTION (IJM\&P)

http://www.ijmp.jor.br

v. 6 , n. 2, April - June 2015

ISSN: 2236-269X

DOI: 10.14807/ijmp.v6i2.282

facets of KM enablers and process capability, or between KM process capabilities and organizational performance.

For example, Tanriverdi (2005) posited that IT relatedness enhances KM capabilities which, in turn, leads to superior firm performance (TANRIVERDI, 2005). Many researchers have emphasized the importance of knowledge infrastructure and processes for KM (CHA; PINGRY; THATCHER, 2008; CHOO; LINDERMAN; SCHROEDER, 2007; LEE; STEEN, 2010; TANRIVERDI, 2005).

Most studies have investigated the relationships of KM enablers, processes, or performance in isolation. For example, Gold et al. (2001) suggested that the knowledge infrastructure capabilities (technology, structure, culture) and the knowledge process capabilities (acquisition, conversion, application, protection) directly affect the organizational effectiveness, but did not show the relationships between the knowledge infrastructure capabilities and knowledge process capabilities (GOLD; MALHOTRA; SEGARS, 2001).

While Lee and Choi (2003) showed the integrated relationships between KM enablers, knowledge creation processes, KM intermediate outcomes, and organizational performance, their study did not consider the whole knowledge process capability but rather focused on the knowledge creation process (LEE; $\mathrm{CHOI}, 2003)$. Furthermore, some important antecedents, such as management related factors, were missing from the study by Lee and Choi (2003).

Nguyen and Neck (2010) have conducted a research under the title of "knowledge management as a dynamic capability: Is it done in less developed countries? "They have investigated the impact of knowledge management process capabilities on competitive advantage in Vietnamese companies (NGUYEN; NECK, 2010).

Their findings revealed that knowledge management process capabilities have a significant impact on creating competitive advantage in companies. Dimitriades (2005) argues that OL is an integral feature of any LO that effectively utilizes its knowledge resources to generate superior performance (DIMITRIADES, 2005).

According to Chattel (1998) if an organization wishes to fulfil KM functions, it must provide a learning environment to maximize its human resources (CHATTEL, 1998). Hong and Kuo (1999) Pemberton and Stonehouse (2000) Loermans (2002) 
INDEPENDENT JOURNAL OF MANAGEMENT \& PRODUCTION (IJM\&P)

http://www.ijmp.jor.br

v. 6 , n. 2, April - June 2015

ISSN: 2236-269X

DOI: 10.14807/ijmp.v6i2.282

argue that a LO generates new knowledge which helps sustain its competitive advantage (HONG; KUO, 1999; PEMBERTON; STONEHOUSE, 2000; LOERMANS, 2002); however, just creating knowledge alone does not mean that knowledge is being efficiently and effectively used or managed.

KM takes the output from the LO (new created knowledge), manages it and ensures that an appropriate environment to perpetuate the generation and management of knowledge capital is being properly maintained. Similarly, Rowly (2000) believes that learning leads to knowledge, which may be either tacit or explicit, while knowledge is available to support and enforce decisions, behavior and actions (ROWLY, 2000). Currie and Kerrin (2003) adopt an OL perspective to reflect more critically upon the problems of KM (CURRIE; KERRIN, 2003). Existing studies have demonstrated a correlation between $\mathrm{OL}$ and $\mathrm{KM}$, such as (THERIOU; CHATZOGLOU, 2008; BATTOR; ZAIRI; FRANCIS, 2008; SENSE, 2007).

\section{THE SUGGESTED RESEARCH MODEL}

Reviewing the previous researches, 7 components have been chosen as subcategories of knowledge management infrastructure capabilities which can be named in the following manner: collaboration, trust and learning culture as subcategories of culture; decentralization as subcategory of structure; top management support and promotion as subcategories of management; and information technology support as subcategory of information technology.

The aforementioned components can improve knowledge creation in the section of knowledge management infrastructure capabilities (LEE; CHOI, 2003). They are also effective in enhancing knowledge management process capabilities such as knowledge creation, transfer, application and storage (HOFFMAN; HOELSCHER; SHERIF, 2005). Creative organizational learning improves through the augmentation of knowledge management process capabilities such as knowledge creation, transfer and application (MALHOTRA, 2004). As a result, enhancement of creative organizational learning will develop organizational performance (PFEFFER, 2005; SHANI; SENA; STEBBINS, 2000). On the basis of the above components, hypothesis of the study are as follows and Figure 1 shows the suggested research model as follows: 
INDEPENDENT JOURNAL OF MANAGEMENT \& PRODUCTION (IJM\&P)

http://www.ijmp.jor.br

v. 6 , n. 2, April - June 2015

ISSN: 2236-269X

DOI: 10.14807/ijmp.v6i2.282

- H1: Collaboration has a significant impact on the knowledge management process capabilities.

- H2: Trust has a significant impact on the knowledge management process capabilities.

- H3: Learning Culture has a significant impact on the knowledge management process capabilities.

- H4: Decentralization has a significant impact on the knowledge management process capabilities.

- H5: Top Management support has a significant impact on the knowledge management process capabilities.

- H6: Promotion has a significant impact on the knowledge management process capabilities.

- H7: IT support has a significant impact on the knowledge management process capabilities.

- H8: knowledge management process capabilities has a significant impact on the Creative Organizational learning.

- H9: Creative Organizational learning has a significant impact on the Organizational performance.

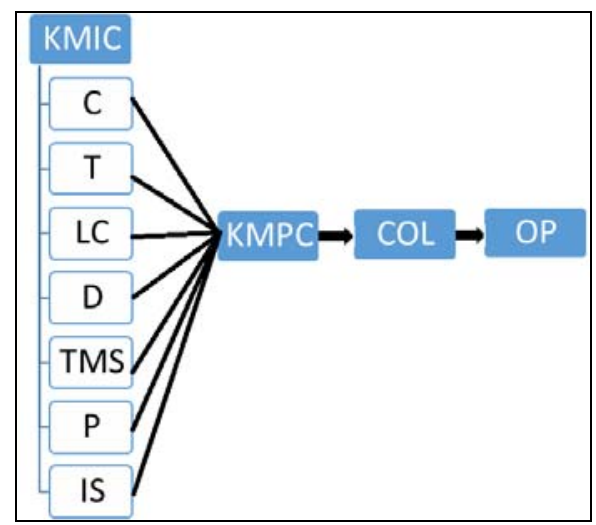

Figure 1:Research model

\section{ESEARCH METHODOLOGY}

\subsection{Measures of variables}

The definitions and measurement items for the research variables in this study are outlined in Tables 1 and 2 . 
The items are adapted from previous studies which have been validated and used for studies in KM. This study adopts and measures four broad dimensions of process capabilities as suggested by (GOLD; MALHOTRA; SEGARS, 2001): the acquisition, conversion, application, and protection of knowledge. Creative organizational learning includes the extent of the ability to make existing knowledge invalid and adjust the understanding of new environments through acquiring new knowledge. Most variables in the model are measured by items written in the form of statements that the respondent agrees or disagrees with to varying degrees using a five-point Likert scale.

Table 1. Definitions of variables

\begin{tabular}{|c|c|c|}
\hline Sources & Definitions & $\begin{array}{l}\text { Research } \\
\text { Variables }\end{array}$ \\
\hline $\begin{array}{l}\text { (SHANI; SENA; STEBBINS, } \\
\text { 2000; LEE; CHOI, 2003) }\end{array}$ & $\begin{array}{l}\text { The extent that people support and help others } \\
\text { tasks while performing their tasks. }\end{array}$ & Collaboration \\
\hline (LEE; CHOI, 2003) & $\begin{array}{l}\text { The extent of beliefs in others behaviors skills } \\
\text { and attitude toward organizational goals. }\end{array}$ & Trust \\
\hline $\begin{array}{l}\text { (SHANI; SENA; STEBBINS, } \\
\text { 2000; LEE; CHOI, 2003) }\end{array}$ & $\begin{array}{l}\text { The extent that organizations facilitate and } \\
\text { encourage opportunities of development and } \\
\text { learning. }\end{array}$ & Learning culture \\
\hline $\begin{array}{l}\text { (CARUANA; MORRIS; } \\
\text { VELLA, 1998; LEE; CHOI, } \\
\text { 2003) }\end{array}$ & $\begin{array}{l}\text { The extent that the decision making authorities } \\
\text { and controls are decentralized in organizations. }\end{array}$ & Decentralization \\
\hline $\begin{array}{l}\text { (CARPENTER, 2001; } \\
\text { O'DELL; GRAYSON, 1999; } \\
\text { SCHEIN, 1985) }\end{array}$ & $\begin{array}{l}\text { The extent that top management understands } \\
\text { and supports knowledge management. }\end{array}$ & $\begin{array}{l}\text { Top management } \\
\text { support }\end{array}$ \\
\hline (BOCK; KIM, 2002) & $\begin{array}{l}\text { The extent that the participation in knowledge } \\
\text { management activities are promoted using } \\
\text { financial and nonfinancial rewards. }\end{array}$ & Promotion \\
\hline $\begin{array}{l}\text { (GOLD; MALHOTRA; } \\
\text { SEGARS, 2001; LEE; CHOI, } \\
\text { 2003) }\end{array}$ & $\begin{array}{l}\text { The collaboration communication search and } \\
\text { access decision making and systematic storage } \\
\text { of information are supported by IT. }\end{array}$ & IT support \\
\hline $\begin{array}{l}\text { (GOLD; MALHOTRA; } \\
\text { SEGARS, 2001; ALAVI; } \\
\text { LEIDNER, 2001) }\end{array}$ & $\begin{array}{l}\text { The capability to obtain knowledge and its } \\
\text { sources. }\end{array}$ & $\begin{array}{l}\text { Knowledge } \\
\text { acquisition }\end{array}$ \\
\hline $\begin{array}{l}\text { (GOLD; MALHOTRA; } \\
\text { SEGARS, 2001; ALAVI; } \\
\text { LEIDNER, 2001) }\end{array}$ & $\begin{array}{l}\text { The capability to change the state or format of } \\
\text { knowledge for its reuse. }\end{array}$ & $\begin{array}{l}\text { Knowledge } \\
\text { conversion }\end{array}$ \\
\hline $\begin{array}{l}\text { (GOLD; MALHOTRA; } \\
\text { SEGARS, 2001; ALAVI; } \\
\text { LEIDNER, 2001) }\end{array}$ & $\begin{array}{l}\text { The capability to transfer and use knowledge for } \\
\text { realization of its values. }\end{array}$ & $\begin{array}{l}\text { Knowledge } \\
\text { application }\end{array}$ \\
\hline $\begin{array}{l}\text { (GOLD; MALHOTRA; } \\
\text { SEGARS, 2001; ALAVI; } \\
\text { LEIDNER, 2001) }\end{array}$ & The capability to exclusively protect knowledge. & $\begin{array}{l}\text { Knowledge } \\
\text { protection }\end{array}$ \\
\hline $\begin{array}{l}\text { (VANDENBOSCH; } \\
\text { HIGGINS, 1996) }\end{array}$ & $\begin{array}{l}\text { The extent to change the understanding of } \\
\text { existing business practices or make them invalid. }\end{array}$ & $\begin{array}{l}\text { Creative } \\
\text { organizational } \\
\text { learning }\end{array}$ \\
\hline $\begin{array}{l}\text { (GOLD; MALHOTRA; } \\
\text { SEGARS, 2001) }\end{array}$ & $\begin{array}{l}\text { The capability to develop new products/services. } \\
\text { The capability to predict business or risks. } \\
\text { The improvement of capability to cope with new } \\
\text { information of markets. }\end{array}$ & $\begin{array}{l}\text { Organizational } \\
\text { performance }\end{array}$ \\
\hline
\end{tabular}


INDEPENDENT JOURNAL OF MANAGEMENT \& PRODUCTION (IJM\&P)

http://www.ijmp.jor.br

v. 6, n. 2, April - June 2015

ISSN: 2236-269X

DOI: 10.14807/ijmp.v6i2.282

Table 2. Measurement items for the research variables (Standard questionnaire)

Co1 The members of our company are willing to take responsibility in the faults which we make.

Co2 The members of our company are cooperative with each other.

Co3 The members of our company are willing to provide support to each other.

Co4 The members of our company share cooperative inter-departmental atmosphere in performing works.

Co5 Members of our company are satisfied with each other in our cooperation.

Tr1 The members of our company believe that they treat each other truthfully.

Tr2 Top management of our company is well aware of the concepts of knowledge management.

Tr3 Top management of our company invests much human and financial resource for knowledge management.

Tr4 Top management of our company emphasizes the importance of knowledge management to organizational members.

Tr5 Top management of our company participates in and leads knowledge management activities (e.g. knowledge sharing and utilization).

Pr1 Our company provides much financial incentives for knowledge sharing.

Pr2 Our company reflects contribution to knowledge sharing activities in personnel evaluation of work performance.

Pr3 Our company sufficiently provides opportunities for education and training as incentives for knowledge sharing activities.

Pr4 Our company sufficiently rewards employees if their contribution or sharing of knowledge leads to organizational performance such as sales growth and cost reduction.

Pr5 Our company respects and acknowledges the honors of employees who contribute to knowledge sharing activities.

IT S1 IT in our company provides environments which enable cooperative working in anytime and anyplace.

IT S2 IT in our company provides environments which enable fast and easy exchange of opinions among organizational members.

IT S3 IT in our company supports fast and easy access to necessary information and knowledge.

ITS4 IT in our company supports various software tools for decision making.

IT S5 IT in our company supports systematic storage of necessary information and knowledge.

AC1 1 The KM processes in our company effectively enables the creation of new knowledge from existing knowledge.

AC2 The KM processes in our company enables learning of useful lessons from previous work experiences.

AC3 The KM processes in our company facilitates exchange of knowledge with other departments (or trading partners).

AC4 The KM processes in our company enables the acquisition of knowledgeof new products and services in industry.

AC5 The KM processes in our company facilitates the acquisition of new knowledge about competitors in industry.

Con1 The KM processes in our company enables the appropriate filtering of large amount of knowledge.

Con2 The KM processes in our company enables the absorption of employees knowledge into organizational knowledge.

Con3 The KM processes in our company enables transfer of partners knowledge into our company s knowledge.

Con4 The KM processes in our company enables the execution of activities for the integration of knowledge from different sources and types.

Con5 The KM processes in our company enables the execution of activities for the abandonment or replacement of outdated knowledge. 
INDEPENDENT JOURNAL OF MANAGEMENT \& PRODUCTION (IJM\&P)

http://www.ijmp.jor.br

ISSN: 2236-269X

DOI: 10.14807/ijmp.v6i2.282

\begin{tabular}{|c|c|}
\hline Ap1 & $\begin{array}{l}\text { The KM processes in our company enables learning knowledge from mistakes and failures } \\
\text { and utilizing the knowledge in works. }\end{array}$ \\
\hline Ap2 & $\begin{array}{l}\text { The KM processes in our company enables utilization of retained knowledge in order to solve } \\
\text { new problems. }\end{array}$ \\
\hline Ap3 & $\begin{array}{l}\text { The KM processes in our company enables diffusion and utilization of knowledge which is } \\
\text { necessary to improve work efficiency. }\end{array}$ \\
\hline Ap4 & $\begin{array}{l}\text { The KM processes in our company enables the distribution of knowledge to organizational } \\
\text { members for applying the knowledge to their works. }\end{array}$ \\
\hline Ap5 & $\begin{array}{l}\text { The KM processes in our company enables the capture and application of knowledge in } \\
\text { critical issues for competition. }\end{array}$ \\
\hline Pro1 & $\begin{array}{l}\text { The KM processes in our company enables the execution of activities for the prevention of } \\
\text { inappropriate usage of knowledge. }\end{array}$ \\
\hline Pro2 & $\begin{array}{l}\text { The KM processes in our company enables the execution of activities for the prevention of } \\
\text { disclosure of knowledge into outside of organization. }\end{array}$ \\
\hline Pro3 & $\begin{array}{l}\text { The KM processes in our company use technology for restricting access to important. } \\
\text { Knowledge sources. }\end{array}$ \\
\hline Pro4 & The KM processes in our company clearly defines knowledge into which access is restricted. \\
\hline Pro5 & $\begin{array}{l}\text { The KM processes in our company clearly deliver the importance of knowledge protection } \\
\text { into employees. }\end{array}$ \\
\hline COL1 & $\begin{array}{l}\text { The knowledge acquired from KMS enables the questioning of our view on the current } \\
\text { business practices. }\end{array}$ \\
\hline COL2 & The knowledge acquired from KMS enables the development of our creativeness. \\
\hline COL3 & $\begin{array}{l}\text { The knowledge acquired from KMS improves our perspectives on the execution of business. } \\
\text { Processes. }\end{array}$ \\
\hline COL4 & The knowledge acquired from KMS enables having views in new direction. \\
\hline COL5 & The knowledge acquired from KMS broadens our views on business practices. \\
\hline COL6 & The knowledge acquired from KMS enables the questioning of our prejudices. \\
\hline OP1 & $\begin{array}{l}\text { After knowledge management systems are introduced the capability to capture new business } \\
\text { opportunities is improved. }\end{array}$ \\
\hline OP2 & $\begin{array}{l}\text { After knowledge management systems are introduced the capability to predict potential } \\
\text { markets for products/services is improved. }\end{array}$ \\
\hline OP3 & $\begin{array}{l}\text { After knowledge management systems are introduced the capability to develop new } \\
\text { products/services is improved. }\end{array}$ \\
\hline OP4 & $\begin{array}{l}\text { After knowledge management systems are introduced the capability to predict unexpected } \\
\text { incidents and crises is improved. }\end{array}$ \\
\hline OP5 & $\begin{array}{l}\text { After knowledge management systems are introduced the capability to rapidly adjust } \\
\text { organizational objectives according to change in industry/markets is improved. }\end{array}$ \\
\hline OP6 & $\begin{array}{l}\text { After knowledge management systems are introduced the capability to respond to new } \\
\text { information regarding industry/markets is improved. }\end{array}$ \\
\hline OP7 & $\begin{array}{l}\text { After knowledge management systems are introduced the capability to respond to new } \\
\text { market demands is improved. }\end{array}$ \\
\hline
\end{tabular}

The Standard questionnaire included 68 questions derived from (GOLD; MALHOTRA; SEGARS, 2001; LEE; CHOI, 2003; ALAVI; LEIDNER, 2001) for KM Process Capability and Hurley and Hult (SHANI; SENA; STEBBINS, 2000; LEE; CHOI, 2003; CARUANA; MORRIS; VELLA, 1998; CARPENTER, 2001; O'DELL; GRAYSON, 1999; SCHEIN, 1985; BOCK; KIM, 2002; GOLD; MALHOTRA; SEGARS, 2001) for Infrastructure Capability and Vandenbosch and Higgins 
INDEPENDENT JOURNAL OF MANAGEMENT \& PRODUCTION (IJM\&P)

http://www.ijmp.jor.br

v. 6, n. 2, April - June 2015

ISSN: 2236-269X

DOI: $10.14807 / i j m p . v 6 i 2.282$

(VANDENBOSCH; HIGGINS, 1996) for Creative Organizational Learning (GOLD; MALHOTRA; SEGARS, 2001 ) for Organizational Performance.

The structural relations among variables were tested using the partial least squares (PLS) method and Sample Random method applied to collect data. The research tool was a standard questionnaire. Regression and correlation methods and SPSS and PLS software were used to assess the collected data. Owing to the fact that this research intends to assess the mediator role of KM process for creative organizational learning. It is an applied, descriptive, correlation survey. It is also a cross-sectional study, since the needed data have assembled during a specific time from a specified target population.

\subsection{Data collecting method}

\subsubsection{Population}

Target population of the research consisted of 86 Top Managers in Science and Technology Park of Tehran which were active in the Electronics and electronic engineering. Bio Renewable Energy Nano and Information and Communication Technologies.

\subsubsection{Sample}

The unit of analysis is a company that has adopted a KMS. The sample of KMS adopting companies was obtained from a list of companies whose top managers have enrolled in the Science and Technology Park of Tehran. Statistical population includes executives of Knowledge based companies in Science and Technology Parks of Tehran. The 68 questionnaire was distributed to the census, 60 questionnaires were completed correctly. The research data were analyzed by PLS software. The unit of analysis is a company that has adopted a KMS.

\subsection{Measures and Statistical Methods}

\subsubsection{Validity and Reliability}

Face validity was used to validate the research tool. So, the questionnaires, as a pretest, were distributed between 5 professors and specialists. Then, they were amended based on their reforms. After that, a sample size of 20 people was chosen and the questionnaires were given to them. Also In this study, to assess the Construct validity was used of the statistical methods of confirmatory factor analysis. 
INDEPENDENT JOURNAL OF MANAGEMENT \& PRODUCTION (IJM\&P)

http://www.ijmp.jor.br

v. 6 , n. 2, April - June 2015

ISSN: 2236-269X

DOI: 10.14807/ijmp.v6i2.282

Factor loadings over 0.4 are considered as acceptable factor loadings and have proper credentials (Table 3 ).

There are also some techniques to evaluate a research reliability, one of which is internal consistency. It can be calculated by Cronbach's alpha coefficient. It is common approach in most of the researches and should be at least 0.7 . The reliability of each variable in this research has calculated and shown in table 4 . This study assesses the measurement properties of the variables using the partial least squares (PLS) method, one of most widely used structural equation modeling (SEM) approaches in information system (IS) research.

The reliability of the inherent variable and individual item is tested using internal consistency reliability and Cronbach's $\alpha$. The factor loadings of the inherent variables in this study are presented in Table 3 As can be observed the factor loadings are greater than 0.4 and Cronbach's $\alpha$ is greater than 0.7 (Table 4), therefore the inherent variables of this study exhibit sufficient reliability. All loadings in this study are greater than 0.7; furthermore, the high values of the loadings, and significant parameter estimates also indicate the presence of convergent validity.

Table 3. Construct Validity

\begin{tabular}{|c|c|c|c|c|c|}
\hline $\begin{array}{l}\text { Inherent } \\
\text { variables }\end{array}$ & Items & Loadings & $\begin{array}{l}\text { Inherent } \\
\text { variables }\end{array}$ & Items & Loadings \\
\hline \multirow{5}{*}{ Collaboration } & Col1 & 0.610 & \multirow{20}{*}{$\begin{array}{c}\text { Knowledge } \\
\text { management } \\
\text { process } \\
\text { capability }\end{array}$} & Ac1 & 0.815 \\
\hline & Col2 & 0.537 & & Ac2 & 0.727 \\
\hline & Col3 & 0.611 & & Ac3 & 0.778 \\
\hline & Col4 & 0.444 & & Ac4 & 0.757 \\
\hline & Col5 & 0.626 & & Ac5 & 0.728 \\
\hline \multirow{5}{*}{ Trust } & T1 & 0.669 & & Con1 & 0.861 \\
\hline & $\mathrm{T} 2$ & 0.636 & & Con2 & 0.821 \\
\hline & T3 & 0.540 & & Con3 & 0.795 \\
\hline & $\mathrm{T4}$ & 0.705 & & Con4 & 0.762 \\
\hline & T5 & 0.642 & & Con5 & 0.674 \\
\hline \multirow{5}{*}{ learning culture } & Lc1 & 0.613 & & Ap1 & 0.753 \\
\hline & Lc2 & 0.445 & & Ap2 & 0.767 \\
\hline & Lc3 & 0.547 & & Ap3 & 0.861 \\
\hline & Lc4 & 0.546 & & Ap4 & 0.847 \\
\hline & Lc5 & 0.688 & & Ap5 & 0.816 \\
\hline \multirow{5}{*}{ Decentralization } & D1 & 0.444 & & Pt1 & 0.744 \\
\hline & D2 & 0.421 & & $\mathrm{Pt} 2$ & 0.776 \\
\hline & D3 & 0.522 & & Pt3 & 0.602 \\
\hline & D4 & 0.446 & & $\mathrm{Pt} 4$ & 0.589 \\
\hline & D5 & 0.600 & & Pt5 & 0.742 \\
\hline Top & Tms1 & 0.737 & Creative & COL1 & 0.491 \\
\hline
\end{tabular}


INDEPENDENT JOURNAL OF MANAGEMENT \& PRODUCTION (IJM\&P)

http://www.ijmp.jor.br

v. 6 , n. 2, April - June 2015

ISSN: 2236-269X

DOI: 10.14807/ijmp.v6i2.282

\begin{tabular}{|c|c|c|}
\hline $\begin{array}{c}\text { management } \\
\text { support }\end{array}$ & Tms2 & 0.636 \\
\cline { 2 - 3 } & Tms3 & 0.645 \\
\cline { 2 - 3 } & Tms4 & 0.795 \\
\cline { 2 - 3 } & Tms5 & 0.825 \\
\hline \multirow{4}{*}{ Promotion } & $\mathrm{P} 1$ & 0.757 \\
\cline { 2 - 3 } & $\mathrm{P} 2$ & 0.706 \\
\cline { 2 - 3 } & $\mathrm{P} 3$ & 0.664 \\
\cline { 2 - 3 } & $\mathrm{P} 4$ & 0.712 \\
\cline { 2 - 3 } & $\mathrm{P} 5$ & 0.836 \\
\hline \multirow{4}{*}{ IT support } & IT1 & 0.624 \\
\cline { 2 - 3 } & IT2 & 0.454 \\
\cline { 2 - 3 } & IT3 & 0.581 \\
\cline { 2 - 3 } & IT4 & 0.447 \\
\cline { 2 - 3 } & IT5 & 0.707 \\
\hline
\end{tabular}

\begin{tabular}{|c|c|c|}
\hline $\begin{array}{c}\text { organizational } \\
\text { learning }\end{array}$ & COL2 & 0.888 \\
\cline { 2 - 3 } & COL3 & 0.931 \\
\cline { 2 - 3 } & COL4 & 0.921 \\
\cline { 2 - 3 } & COL5 & 0.901 \\
\cline { 2 - 3 } & COL6 & 0.429 \\
\hline \multirow{4}{*}{$\begin{array}{c}\text { Organizational } \\
\text { performance }\end{array}$} & OP1 & 0.883 \\
\cline { 2 - 3 } & OP2 & 0.898 \\
\cline { 2 - 3 } & OP3 & 0.857 \\
\cline { 2 - 3 } & OP4 & 0.689 \\
\cline { 2 - 3 } & OP5 & 0.806 \\
\cline { 2 - 3 } & OP6 & 0.918 \\
\cline { 2 - 3 } & OP7 & 0.865 \\
\hline
\end{tabular}

Table 4. Cronbach's Alpha

\begin{tabular}{|l|l|l|}
\hline Latent variable & Dimensions & Cronbach's alpha \\
\hline KM Infrastructure Capability & 35 & 0.951 \\
\hline KM Process Capability & 20 & 0.962 \\
\hline $\begin{array}{l}\text { Creative Organizational } \\
\text { Learning }\end{array}$ & 6 & 0.873 \\
\hline Organizational Performance & 7 & 0.934 \\
\hline
\end{tabular}

\subsubsection{Kolmogorov-Smirnov test}

One of the most important assumptions the Pearson's correlation and regression is the assumption of normality of the data set. As seen in the table 5 for all variables, significance level is more than 5 percent ,so it can be stated that all variables are normally distributed in this study.

Table 5. Kolmogorov-Smirnov test

\begin{tabular}{|l|l|l|l|l|l|}
\hline \multirow{2}{*}{ Number } & \multicolumn{2}{|l|}{ Normal parameters } & Statistic & $\begin{array}{l}\text { Level of } \\
\text { significance }\end{array}$ & Criterion validities \\
\cline { 2 - 5 } & Mean & $\begin{array}{l}\text { Standard } \\
\text { deviation }\end{array}$ & & & \\
\hline 60 & 3.509 & 0.6275 & 0.777 & 0.581 & KM infrastructure capabilities \\
\hline 60 & 3.407 & 0.8228 & 1.063 & 0.208 & KM process capabilities \\
\hline 60 & 3.661 & 0.8136 & 1.199 & 0.113 & Creative organizational learning \\
\hline 60 & 3.652 & 0.8784 & 1.136 & 0.152 & Organizational performance \\
\hline
\end{tabular}

\subsubsection{Bartlett test and the Kaiser criterion}

"KMO" Index will determine the suitability of data for factor analysis. The value of this statistic varies between zeros to one. For a good sample ,the value of this statistic must be larger than0.5.In this study is equal 0.842 (Table 6). Therefore factor analysis is suitable for this data set .If the "Bartlett's test" is significant there is a correlation between variables and factor analysis is possible in this study a 
INDEPENDENT JOURNAL OF MANAGEMENT \& PRODUCTION (IJM\&P)

http://www.ijmp.jor.br

v. 6 , n. 2, April - June 2015

ISSN: 2236-269X

DOI: 10.14807/ijmp.v6i2.282

significant amount is less than the then 0.5 , therefore factor analysis is appropriate (Table 6).

Table 6. Bartlett Test

\begin{tabular}{|l|l|}
\hline \multicolumn{2}{|c|}{ Bartlett Test } \\
\hline $\begin{array}{l}\text { Kaiser- Meyer- Olkin } \\
\text { (KMO) }\end{array}$ & $\mathbf{0 . 8 4 2}$ \\
\hline Statistic of Rotation Test & 362.259 \\
\hline Significance & 0.000 \\
\hline
\end{tabular}

\subsubsection{Goodness of Fitness}

The most important indicator for determining the validation of the model is absolute, relative and internal and external Indicators. These four indicators, are fitted the quality of the models. Due to the high number is obtained, relatively good fit. Therefore has been provided the good coincidence between the structural models with experimental data. (Table7).

Table 7. Goodness of fit index
\begin{tabular}{|l|l|}
\hline Goodness of fit index \\
\hline & GoF \\
\hline Absolute & 0.485 \\
\hline Relative & 0.768 \\
\hline Outer model & 0.998 \\
\hline Inner model & 0.770 \\
\hline
\end{tabular}

On the basis of the above components, Figure 2 shows the Structural Model research model as follows.

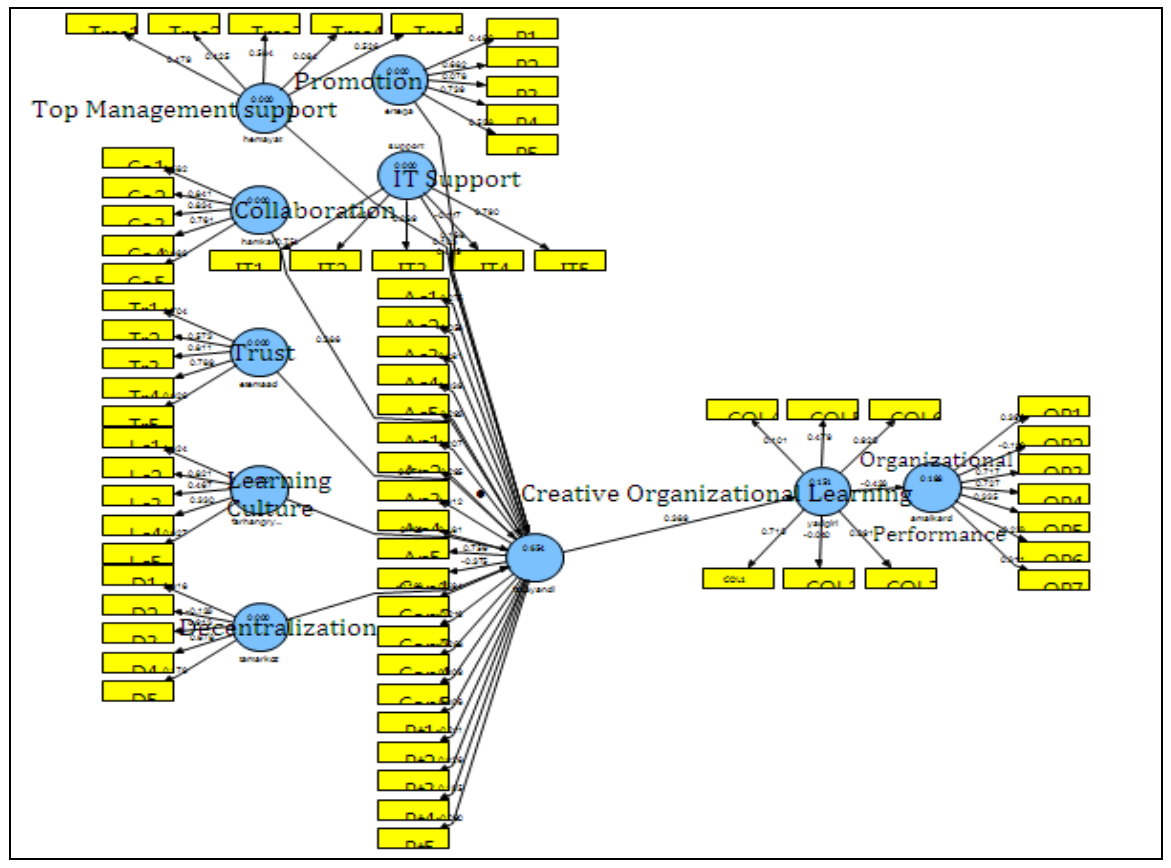

Figure 2: Test of Structural Model 
INDEPENDENT JOURNAL OF MANAGEMENT \& PRODUCTION (IJM\&P)

http://www.ijmp.jor.br

v. 6 , n. 2, April - June 2015

ISSN: 2236-269X

DOI: 10.14807/ijmp.v6i2.282

\subsubsection{Methods of data analysis}

The industry distribution of the responding companies and the characteristics of respondents are presented in Tables 8 and 9.

Table 8: Demographic profile of respondents

\begin{tabular}{|c|c|c|c|c|c|c|c|c|c|c|c|c|c|}
\hline \multicolumn{4}{|c|}{ Work Experience } & \multicolumn{4}{|c|}{ Age } & \multicolumn{3}{|c|}{ Education } & \multicolumn{2}{|c|}{ Sex } & \multirow{2}{*}{$\begin{array}{l}\text { Dem } \\
\text { ogra } \\
\text { phic }\end{array}$} \\
\hline $\begin{array}{l}15- \\
20\end{array}$ & $\begin{array}{l}10- \\
15\end{array}$ & $5-10$ & $1-5$ & $50<$ & $\begin{array}{l}40- \\
50\end{array}$ & $\begin{array}{l}30- \\
40\end{array}$ & $20-30$ & PhD & MA & Bsc & $\mathrm{F}$ & $M$ & \\
\hline 3 & 1 & 16 & 40 & 1 & 2 & 23 & 34 & 3 & 20 & 37 & 16 & 44 & 60 \\
\hline
\end{tabular}

Table 9: characteristic of responding Companies

\begin{tabular}{|l|l|}
\hline \multicolumn{1}{|c|}{ Industry Type } & Frequency \\
\hline Electrical and Electronic Engineering & 32 \\
\hline Bio & 12 \\
\hline Information and Communication & 7 \\
\hline Nano & 4 \\
\hline Renewable Energy & 5 \\
\hline Total & 60 \\
\hline
\end{tabular}

Table10. Pearson's correlation coefficient between the variables

\begin{tabular}{|c|c|c|c|c|c|c|c|c|c|c|c|}
\hline \multicolumn{12}{|c|}{ Correlations } \\
\hline & & Col & $T$ & Lc & D & Tms & $\mathrm{P}$ & IT & $\begin{array}{l}\text { ghfarayan } \\
\text { dikm }\end{array}$ & $\mathrm{COL}$ & OP \\
\hline \multirow[t]{2}{*}{$\mathrm{Col}$} & Pearson Correlation & 1 & $.710^{* *}$ & $.429^{* *}$ & $.545^{\star \star *}$ & $.484^{* *}$ & $.580^{* *}$ & $.331^{* *}$ & $.521^{\star \star *}$ & .225 & .208 \\
\hline & $\mathrm{N}$ & 60 & 60 & 60 & 60 & 60 & 60 & 60 & 60 & 60 & 60 \\
\hline \multirow[t]{2}{*}{$\mathrm{T}$} & Pearson Correlation & $.710^{* *}$ & 1 & $.600^{* *}$ & $.505^{\star *}$ & $.638^{\star *}$ & $.629^{* *}$ & $.495^{\star *}$ & $.567^{\star \star}$ & $.292^{*}$ & $.263^{*}$ \\
\hline & Sig. (2-tailed) & .000 & & .000 & .000 & .000 & .000 & .000 & .000 & .024 & .043 \\
\hline \multirow{2}{*}{ Lc } & Sig. (2-tailed) & .001 & .000 & & .025 & .000 & .000 & .000 & .000 & .001 & .089 \\
\hline & $\mathrm{N}$ & 60 & 60 & 60 & 60 & 60 & 60 & 60 & 60 & 60 & 60 \\
\hline \multirow[t]{3}{*}{$\mathrm{D}$} & Pearson Correlation & $.545^{\star *}$ & $.505^{\star \star *}$ & $.289^{*}$ & 1 & $.391^{* *}$ & $.446^{\star \star}$ & .249 & $.357^{\star \star *}$ & $.399^{* *}$ & $.404^{\star \star *}$ \\
\hline & Sig. (2-tailed) & .000 & .000 & .025 & & .002 & .000 & .055 & .005 & .002 & .001 \\
\hline & $\mathrm{N}$ & 60 & 60 & 60 & 60 & 60 & 60 & 60 & 60 & 60 & 60 \\
\hline Tms & Pearson Correlation & $.484^{\star \star}$ & $.638^{* *}$ & $.559^{* \star}$ & $.391^{* \star}$ & 1 & $.832^{* *}$ & $.647^{* *}$ & $.620^{* *}$ & $.437^{\star *}$ & $.488^{\star \star}$ \\
\hline $\mathrm{P}$ & $\mathrm{N}$ & 60 & 60 & 60 & 60 & 60 & 60 & 60 & 60 & 60 & 60 \\
\hline \multirow[t]{3}{*}{ IT } & Pearson Correlation & $.331^{* \star}$ & $.495^{\star \star}$ & $.545^{\star \star}$ & .249 & $.647^{* *}$ & $.618^{* *}$ & 1 & $.680^{* *}$ & $.257^{*}$ & $.261^{\star}$ \\
\hline & Sig. (2-tailed) & .010 & .000 & .000 & .055 & .000 & .000 & & .000 & .047 & .044 \\
\hline & $\mathrm{N}$ & 60 & 60 & 60 & 60 & 60 & 60 & 60 & 60 & 60 & 60 \\
\hline \multirow[t]{3}{*}{ ghfarayandikm } & Pearson Correlation & $.521^{* \star}$ & $.567^{* \star}$ & $.678^{* *}$ & $.357^{* *}$ & $.620^{* *}$ & $.703^{* *}$ & $.680^{\star *}$ & 1 & $.441^{* *}$ & $.339^{\star \star *}$ \\
\hline & Sig. (2-tailed) & .000 & .000 & .000 & .005 & .000 & .000 & .000 & & .000 & .008 \\
\hline & $\mathrm{N}$ & 60 & 60 & 60 & 60 & 60 & 60 & 60 & 60 & 60 & 60 \\
\hline \multirow[t]{3}{*}{$\overline{\mathrm{COL}}$} & Pearson Correlation & .225 & $.292^{*}$ & $.425^{\star \star}$ & $.399^{* *}$ & $.437^{\star *}$ & $.450^{* *}$ & $.257^{*}$ & $.441^{* *}$ & 1 & $.677^{\star \star \star}$ \\
\hline & Sig. (2-tailed) & .084 & .024 & .001 & .002 & .000 & .000 & .047 & .000 & & .000 \\
\hline & $\mathrm{N}$ & 60 & 60 & 60 & 60 & 60 & 60 & 60 & 60 & 60 & 60 \\
\hline \multirow[t]{3}{*}{$\mathrm{OP}$} & Pearson Correlation & .208 & $.263^{\star}$ & .221 & $.404^{* *}$ & $.488^{\star *}$ & $.417^{\star \star *}$ & $.261^{*}$ & $.339^{\star *}$ & $.677^{* *}$ & 1 \\
\hline & Sig. (2-tailed) & .111 & .043 & .089 & .001 & .000 & .001 & .044 & .008 & .000 & \\
\hline & $\mathrm{N}$ & 60 & 60 & 60 & 60 & 60 & 60 & 60 & 60 & 60 & 60 \\
\hline
\end{tabular}

This correlation shows that a change in each variable will also change the According to Table 10; there is a significant and positive correlation between all 
INDEPENDENT JOURNAL OF MANAGEMENT \& PRODUCTION (IJM\&P)

http://www.ijmp.jor.br

v. 6 , n. 2, April - June 2015

ISSN: 2236-269X

DOI: 10.14807/ijmp.v6i2.282

variables. Other at the same direction in a way that whenever a variable increases, the other will rise too, and whenever it decreases, the other one will decrease too.

\subsubsection{Method of analysis and interpretation of regression test and paths coefficient}

Amount of column 2 in the table 11 are the paths coefficients latent variables on the operating variables, (Reg). Amount of column $4(\operatorname{Pr}>|\mathrm{t}|)$ are probability values, which by them are considered significantly of Paths. If the value is less than 0.05 , the path and the desired path coefficients are significant.

Table 11. Test Results of Structural Model

\begin{tabular}{|l|c|c|c|c|c|}
\hline Hypothesis & $\begin{array}{c}\text { Path } \\
\text { Coefficient }\end{array}$ & $\boldsymbol{T}$ & $\boldsymbol{P r}>|\boldsymbol{t}|$ & $\boldsymbol{R}$ & $\boldsymbol{R}$ \\
\hline H1: Collaboration & 0.690 & 9.224 & 0.000 & Confirmed & - \\
\hline H2: Trust & 0.539 & 8.408 & 0.000 & Confirmed & - \\
\hline H3: Learning Culture & 0.302 & 6.834 & 0.000 & Confirmed & - \\
\hline H4: Decentralization & 0.183 & 5.165 & 0.000 & Confirmed & - \\
\hline H5: Top Management & 0.098 & 3.946 & 0.000 & Confirmed & - \\
\hline H6: Promotion & 0.194 & 5.293 & 0.000 & Confirmed & - \\
\hline H7: IT support & 0.761 & 10.219 & 0.000 & Confirmed & - \\
\hline H8: Creative learning & 0.797 & 10.341 & 0.000 & Confirmed & 0.631 \\
\hline $\begin{array}{l}\text { H9: Organizational } \\
\text { performance }\end{array}$ & 0.813 & 10.924 & 0.000 & Confirmed & 0.781 \\
\hline
\end{tabular}

\subsubsection{Hypothesis Testing}

Table 11 present the test results of the hypotheses. In the first hypothesis (H1), the effect of Collaboration on KM process capabilities assessed. The obtained results $(0.000$ less than 0.05$)$ showed that there is a significant and positive effect between Collaboration and KM process capabilities.

In the second hypothesis $(\mathrm{H} 2)$, Table 11 shows the value of $\operatorname{Pr}>|t|(0.000)$ is less than 0.05 . Therefore there is a significant and positive effect between Trust and $\mathrm{KM}$ process capabilities. Also the same way, other hypotheses were confirmed. From the table 11 can be derived which about $\% 65$ of the variation in $\mathrm{KM}$ processes is discussed by incoming parameters (KM infrastructure capabilities).

Also can be seen in the table that about $\% 63$ of the variation in creative organizational learning is discussed by incoming parameter (KM processes) and also about \%78 of the variation in organizational performance is discussed by the incoming variable (creative organizational learning). 
INDEPENDENT JOURNAL OF MANAGEMENT \& PRODUCTION (IJM\&P)

http://www.ijmp.jor.br

v. 6 , n. 2, April - June 2015

ISSN: 2236-269X

DOI: $10.14807 / i j m p . v 6 i 2.282$

\section{DISCUSSION}

This study integrates the theory of organizational strategy, IT, and organizational learning in order to build an integrated model for KM that examines the relationship between $\mathrm{KM}$ infrastructure, knowledge process capability supported by KMS, creative organizational learning, and organizational performance. The results provide strong evidence for a causal relationship between the constructs underlying the conceptual model presented in this article there are several key findings, which are discussed separately.

The first main finding is the significant path relationship between Collaboration and KM process capabilities (69 percent). Collaboration significantly affects knowledge process capabilities and this indicates that the culture of collaboration contributes to the creation of new knowledge by sharing experiences and knowledge among organizational members and by assisting others in performing tasks.

The second major finding is that there is a significant and positive effect between trust and KM process capabilities. From the table 11can be derived which Path Coefficient is 0.53 .

Another important finding was that Learning Culture has a positive effect on the KM process capabilities (0.30). The learning culture has a positive effect on knowledge process capability and this indicates that the learning culture facilitates the acquisition of new knowledge and the creation of new knowledge from knowledge exchanges and experiences. A culture that promotes and facilitates learning has a strong influence on the capabilities of knowledge creation, acquisition, transfer, and application.

The results of this study indicate that there is a positive effect between decentralization and $\mathrm{KM}$ process capabilities (0.18). The results of the study, however, consistent the previous notion that ensuring autonomous decision making hierarchy will improve KM processes by facilitating active participation in organizational problem solving and the execution of necessary tasks.

Another finding was that Top Management has a positive effect on the KM process capabilities (0.09). This finding is in agreement with Schein's (1985) findings which showed top management support has a strong effect on knowledge process capabilities, and this shows that top management has a strong influence on building 
INDEPENDENT JOURNAL OF MANAGEMENT \& PRODUCTION (IJM\&P)

http://www.ijmp.jor.br

v. 6 , n. 2, April - June 2015

ISSN: 2236-269X

DOI: 10.14807/ijmp.v6i2.282

organizational culture and norms. But the support from top management may not be required less after KMS and incentive systems are developed and completed. Knowledge acquisition and conversion processes are activities undertaken early in building KMS for accumulating organizational knowledge (ALAVI; LEIDNER, 2001).

The results of this study indicate that there is a positive effect between Promotion and KM process capabilities (0.19). This interpretation is consistent with the notion that promotion and incentive systems for times and effort spent in sharing knowledge may improve knowledge process capabilities by providing extrinsic benefits to organizational members.

A strong relationship between IT support and KM process capabilities has been found (0.76). IT support has a strong effect on knowledge process capabilities as it contributes to the creation and sharing of knowledge with smaller costs and is a critical element in KM (ALAVI; LEIDNER, 2001).

The study results support the notion of previous studies that IT improves KM processes which in turn affects organizational learning and performance (HANDZIC, 2004). The KMS that facilitates the creation of new knowledge and updating knowledge enhances the opportunity to create (MALHOTRA, 2004).

The most interesting finding was that a strong relationship between KM process capabilities and Creative organizations learning has been found (0.79). This finding is in agreement with Dimitriades (2005) argues that effective learning requires the development of a strategic learning capability by linking $\mathrm{OL}$ and $\mathrm{KM}$ in and among organizations (DIMITRIADES, 2005).

These results agree with Theriou and Chatzoglou (2008) who demonstrated that the $\mathrm{KM}$ and $\mathrm{OL}$ play their own unique role in creating organizational capabilities, which lead to superior performance (THERIOU; CHATZOGLOU, 2008).

This supports the results from previous studies that Creative organizational learning improves through the augmentation of knowledge management process capabilities such as knowledge creation, transfer and application (MALHOTRA, 2004).

Firestone and McElroy (2004) argue that the relationship of OL and $\mathrm{KM}$ is close enough to be termed intimate (FIRESTONE; MCELROY, 2004). Recent studies 
INDEPENDENT JOURNAL OF MANAGEMENT \& PRODUCTION (IJM\&P)

http://www.ijmp.jor.br

v. 6 , n. 2, April - June 2015

ISSN: 2236-269X

DOI: $10.14807 / i j m p . v 6 i 2.282$

have indicated the positive relationship between $\mathrm{OL}$ and knowledge management capability (LEMON; SAHOTA, 2004). This study shows that the KM processes can mediate between factors in the KM infrastructure (i.e. collaboration, learning culture, and IT support), and creative organizational learning.

These results agree with Lee and Choi (2003) who demonstrated that the knowledge creation process is a mediator between $\mathrm{KM}$ enablers (such as collaboration, trust, learning, and decentralization), and organizational creativity (LEE; CHOI, 2003).

This supports the results from previous studies that KM processes based on IT enhance the breadth and depth for knowledge creation, transfer, and application (ALAVI; LEIDNER, 2001).

Another important finding was that creative organizational learning have a significant impact on the organizational performance (0.81) which is supported by several studies, such as (PFEFFER, 2005; TIWANA, 2002) and this agrees with (GOLD; MALHOTRA; SEGARS, 2001) who state that knowledge process capabilities are related to organizational effectiveness.

Organizational effectiveness depends on the extent to which the knowledge process capabilities increase organizational learning. There is a general consensus in the literature that knowledge management is linked to organizational performance (GOLD; MALHOTRA; SEGARS, 2001; GOSH; SCOTT, 2007; LEE; SUKOCO, 2007; LIU; CHEN; TSAI, 2005; ZAIM; TATOGLU; ZAIM, 2007).

The significant effect of creative organizational learning on organizational performance demonstrates that organizational learning is a KM intermediate outcome that exists between the knowledge process capabilities and organizational performance, which supports the results of Lee and Choi (2003) who posited that organizational creativity mediates the relationship between the knowledge creation process and organizational performance (LEE; CHOI, 2003).

\section{CONCLUSION}

This study makes important contributions in several ways. The integrated model proposed and used in this study for the purpose of developing a KM enabling 
INDEPENDENT JOURNAL OF MANAGEMENT \& PRODUCTION (IJM\&P)

http://www.ijmp.jor.br

v. 6 , n. 2, April - June 2015

ISSN: 2236-269X

DOI: 10.14807/ijmp.v6i2.282

environment in a knowledge-based organization is perhaps one of the most important contributions to $\mathrm{KM}$ literature. The model was validated in the construct aspect.

This study analyzes the relationship between KM infrastructures, knowledge process capabilities, creative organizational learning, and organizational performance. An integrative research model is built based on relevant theories and is empirically tested using a sample of companies that have adopted knowledge management systems (KMS). This essay has argued that a knowledge process capability is the effective instrument to increase creative organizational learning.

\subsection{Implications for practitioners}

This study can provide KM managers and practitioners with guidelines and implementation strategies for KMS by examining cultural, structural, management, and IT related factors. The accumulation of knowledge is inseparable from companies' activities: the products and services provided by companies are dependent upon the unique method that combines companies' tangible resources, and this is the role of KM. The continuous learning and experiments are necessary in order to produce new ideas and products: it is critical to emphasize the importance of a KM infrastructure that supports and encourages learning in organizations.

The creative learning in turn affects organizational performance indicating that without learning, organizations cannot overcome the boundary of old business practices and adjust to change in environments. The tasks of knowledge work are less determined and planned in advance than other work. In order to manage rapid change and global competition in business environments, knowledge workers should create new business opportunities and continuously question what and how they can contribute to these chances. Organizational KMS should support the learning processes of their knowledge workers.

\subsection{Implications for researchers}

Using a holistic view of the KM performance framework, this study has provided insights to KM for researchers because it explains the integrated aspects of $\mathrm{KM}$ performance by examining the relationships between the KM infrastructure, knowledge process capabilities, and organizational outcomes. Previous studies on $\mathrm{KM}$ have been fragmented because they only consider some aspects of KM performance rather than using a holistic view of the KM performance framework: they 
INDEPENDENT JOURNAL OF MANAGEMENT \& PRODUCTION (IJM\&P)

http://www.ijmp.jor.br

v. 6 , n. 2, April - June 2015

ISSN: 2236-269X

DOI: 10.14807/ijmp.v6i2.282

have examined the relationship between one or two facets of $\mathrm{KM}$ enablers and process capability, or between KM process capabilities and organizational performance

\subsection{Suggestions and limitations}

Owing to the fact that customers are of great importance in business world and organization's success, it is suggested to examine the effect of customers' knowledge management on organizational performance by the application of a specific model or its assimilation to the suggested model in the current research.

Although this study provides interesting results regarding $\mathrm{KM}$, the results should be interpreted in light of the study's limitations and provide some future directions for research. First, the present study has focused just on small companies, so these results should not be generalized to all companies with different competitive and organizational structures. Second, the sample is based on Tehranian firms. Because the collections were limited to organizations in a highly collectivist national culture, any attempt to generalize the results to other countries with distinctly different national cultures should be proceeded with caution.

\section{REFERENCES}

ALAVI, M.; LEIDNER, D. E. (2001) Review: Knowledge Management and Knowledge Management Systems: Conceptual Foundations and Research Issues, MIS

Quarterly, v. 25, n. 1, p. 107-136.

AUJIRAPONGPAN, S.; VADHANASINDHU, P.; CHANDRACHAI, A.; COOPARAT, P. (2010) Indicators of knowledge management capability for KM effectiveness, Journal of Information and Knowledge Management Systems, v. 40, n. 2, p. 183203.

BATTOR, M.; ZAIRI, M.; FRANCIS, A. (2008) Knowledge-based capabilities and their impact on performance: a best practice management evaluation, Business Strategy Series, v. 9, n. 2, p. 47-56.

BOCK, G. W.; KIM, Y. G. (2002) Breaking the myths of rewards: an exploratory study of attitudes about knowledge sharing, Information Resource Management Journal, v. 15, n. 2, p. 14-21.

CARPENTER, M. F. J. (2001) Top management teams, global strategic posture, and the moderating role of uncertainty, Academy of Management Journal, v. 44, n. 3, p. 533-545.

CARUANA, A.; MORRIS, M. H.; VELLA, A. J. (1998) The effect of centralization and formalization on entrepreneurship in export firms, Journal of Small Business Management, v. 36, n. 1, p. 16-29. 
CHA, H. S.; PINGRY, D. E.; THATCHER, M. E. (2008) Managing the knowledge supply chain: an organizational learning model of information technology offshore outsourcing, MIS Quarterly, v. 32, n. 2, p. 281-306.

CHATTEL, A. (1998) Creating Value in the Digital Era, London: Macmillan Press. CHONG, S. C.; SALLEH, K.; SYED AHMAD, S.; SHARIFUDDIN, S. O. (2011) KM implementation in a public sector accounting organization: an empirical investigation, Journal of Knowledge Management, v. 15, n. 3, p. 497-512.

CHOO, A. S.; LINDERMAN, K. W.; SCHROEDER, R. G. (2007) Method and psychological effects on learning behaviors and knowledge creation in quality improvement projects, Management Science, v. 53, n. 3, p. 437-450.

CURRIE, G.; KERRIN, M. (2003) The limits of a technological fix to knowledge management: epistemological, political and cultural issues in the case of intranet implementation, Management Learning, v. 35, n. 1, p. 9-29.

DIMITRIADES, Z. S. (2005) Creating strategic capabilities, organizational learning and knowledge management in the new economy, European Business Review, $v$. 17 , n. 4, p. 314-324.

FIRESTONE, J. M.; MCELROY, M. W. (2004) Organizational learning and knowledge management: the relationship, The Learning Organization, v. 11, n. 2, p. 177-184.

GOLD, A. H.; MALHOTRA, A.; SEGARS, A. H. (2001) Knowledge management: an rganizational capabilities perspective, Journal of Management Information Systems, v. 18, n. 1, p. 185-214.

GOSH, B.; SCOTT, J. E. (2007) Effective knowledge management systems for a clinical nursing setting, Information Systems Management, v. 24, n. 1, p. 73-84.

GRAY, P. H.; DURCIKOVA, A. (2005) The role of knowledge repositories in technical support environments: speed versus learning in user performance, Journal of Management Information Systems, v. 22, n. 1, p. 159-190.

HANDZIC, M. (2004) Knowledge Management: Through the Technology Glass, Toh Tuck Link, Singapore.

HOFFMAN, J. J.; HOELSCHER, M. L.; SHERIF, K. (2005) Social capital, knowledge management, and sustained superior performance, Journal of Knowledge

Management, v. 9, n. 3, p. 93-100.

HONG, J. C.; KUO, C. L. (1999) Knowledge management in the learning organization, The Leadership \& Organization Development Journal, v. 20, n. 4, p. 207-215.

HURLEY, R. H. G. (1998) Innovation, market orientation, and organizational learning: an integration and empirical examination, Journal of Marketing, v. 62, n. 3, p. 42-54.

KHALIFA, M.; LIU, V. (2003) Determinants of Successful Knowledge Management Programs, Electronic Journal on Knowledge Management, v. 1, n. 2, p. 107.

KULKARNI, U. R.; RAVINDRAN, S.; FREEZE, R. (2007) A knowledge management success model: theoretical development and empirical validation, Journal of

Management Information Systems, v. 23, n. 3, p. 309-347. 
LEE, D.; STEEN, E. V. (2010) Managing know-how, Management Science, v. 56, n. 2, p. $270-285$.

LEE, H.; CHOI, B. (2003) Knowledge management enablers, processes, and organizational performance: an integrative view and empirical examination, Journal of Management Information Systems, v. 20, n. 1, p. 179-228.

LEE, L. T.; SUKOCO, B. M. (2007) The effects of entrepreneurial orientation and knowledge management capability on organizational effectiveness in Taiwan: the moderating role of social capital, International Journal of Managemen, v. 24, n. 3, p. 549-573.

LEMON, M.; SAHOTA, P. S. (2004) Organizational culture as a knowledge repository for increased innovative capacity, Technovation, v. 24, p. 483-498.

LIU, P. L.; CHEN, W. C.; TSAI, C. H. (2005) An empirical study on the correlation between the knowledge management method and new product development strategy on product performance in Taiwan's industries, Technovation, v. 25, n. 7, p. 637644.

LOERMANS, J. (2002) Synergizing the learning organization and knowledge management, Journal of Knowledge Management, v. 6, n. 3, p. 285-294.

MALHOTRA, Y. (2004) Why knowledge management systems fail? Enablers and constraints of knowledge management in human enterprise, in Knowledge Management Lessons Learned: What Works and What Doesn't, Information Today, M. E. Koenig and K. Srikantaiah, Eds., Medford, NJ, p. 87-112.

MASON, J. (2004) From e-learning to e-knowledge, in KM Tools and Techniques: Practitioners and Experts Evaluate KM Solutions, M. Rao, Ed., ButterworthHeinemann, Oxford, p. 320-328.

MCKEEN, J. D.; ZACK, M. H.; SATYENDRA, S. (2006) Knowledge Management and Organizational Performance: An Exploratory Survey, in Proceedings of the 39th Hawaii International Conference on System Sciences, Hawaii, 2006.

METAXIOTIS, K.; ERGAZAKIS, K.; PSARRAS, J. (2005) Exploring the world of knowledge management: agreements and disagreements in the academic/practitioner community, Journal of Knowledge Management, v. 9, n. 2, p. 6-18.

MILLS, A. M.; SMITH, T. A. (2011) Knowledge management and organizational performance: A decomposed view, Journal of Knowledge Management, v. 15, n. 1, p. 156-171.

NGUYEN, Q.; NECK, P. (2010) Knowledge Management as Dynamic Capabilities: Does It Work in Emerging Less Developed Countries?, Journal of Knowledge Management, v. 3, n. 3, p. 505-520, 2010.

NONAKA, I.; KONNO, N. (1998) The concept of "Ba": building a foundation for knowledge creation, California management review, v. 40, n. 3, p. 40-54.

O'DELL, C.; GRAYSON, C. J. (1999) Knowledge transfer: discover your value proposition, Strategy and Leadership, v. 27, n. 2, p. 10-15.

PEMBERTON, J. D.; STONEHOUSE, G. H. (2000) Organizational learning and knowledge assets - an essential partnership, The Learning Organization, v. 7, n. 4, p. 184-194. 
INDEPENDENT JOURNAL OF MANAGEMENT \& PRODUCTION (IJM\&P)

PFEFFER, J. (2005) Changing mental models: HR's most important task, Human Resource Management, v. 44, n. 2, p. 123-128.

RIVERA-VAZQUEZ, J. C.; ORTIZ-FOURNIER, L. V.; FLORES, F. R. (2009) Overcoming cultural barriers for innovation and knowledge sharing, Journal of Knowledge Management, v. 13, n. 5, p. 257-270.

ROWLY, J. (2000) From learning organization to knowledge entrepreneur, Journal of Knowledge Management, v. 4, n. 1, p. 7-15.

RUGGLES, R. L. (1998) The state of the notion: knowledge management in practice, California Management Review, v. 40, n. 3, p. 80-89.

SCHEIN, E. (1985) Organizational Culture and Leadership: A Dynamic View, San Francisco, CA: Jossey-Bass.

SENSE, A. J. (2007) Stimulating situated learning within projects: personalizing the flow of knowledge, Knowledge Management Research \& Practice, v. 5, n. 1, p. 1321.

SHANI, A. B.; SENA, J. A.; STEBBINS, M. W. (2000) Knowledge work teams and groupware technology: learning from Seagate's experience, Journal of Knowledge Management, v. 4, n. 2, p. 11-124.

SUN, P. (2010) Five critical knowledge management organizational themes, Journal of Knowledge Management, v. 14, n. 4, p. 507-523.

TANRIVERDI, H. (2005) Information technology relatedness, knowledge management capability, and performance of multibusiness firms, MIS Quarterly, v. 29, n. 2, p. 311-341.

THERIOU, G. N.; CHATZOGLOU, P. D. (2008) Enhancing performance through best HRM practices, organizational learning and knowledge management: a conceptual framework, European Business Review, v. 20, n. 3, p. 185-207.

TIWANA, A. (2002) Knowledge Management Toolkit: Orchestrating IT, Strategy and Knowledge Platforms, Upper Saddle River, NJ: Prentice Hall.

VANDENBOSCH, B.; HIGGINS, C. (1996) Information acquisition and mental models: an investigation into the relationship between behaviour and learning, Information Systems Research, v. 7, n. 2, p. 198-214, 1996.

WEN, Y. (2009) An effectiveness measurement model for knowledge management, Knowledge-Based Systems, v. 1, n. 22, p. 363-367.

ZAIM, H.; TATOGLU, E.; ZAIM, S. (2007) Performance of knowledge management practices: a causal analysis, Journal of Knowledge Management, v. 13, n. 6, p. 392-409.

ZINS, C. (2007) Conceptual Approaches for Defining Data, Information, and Knowledge, Journal of the American Society for Information Science and Technology, v. 58, n. 4, p. 479- 493. 